\title{
PROCJENA UČINKOVITOSTI ODRŽIVIH SUSTAVA ODVODNJE OBORINSKIH VODA NA PRIMJERU SVEUČILIŠNOG KAMPUSA NA TRSATU
}

\author{
EFFICIENCY ASSESSMENT OF SUSTAINABLE \\ URBAN DRAINGE SYSTEMS AT UNIVERSITY \\ CAMPUS TRSAT
}

Andrea Maretić, Nino Krvavica**

\begin{abstract}
Sažetak
U ovome radu provedena je analiza sustava za odvodnju oborinskih voda s područja Sveučilišnog kampusa u Rijeci. Pored klasičnog razdjelnog sustava, predložen je $i$ održivi sustav odvodnje oborinskih voda. Učinkovitost ovog prijedloga procijenjena je pomoću hidrološko-hidrauličkog modela. Rezultati su pokazali da implementacija održivog sustava odvodnje oborinskih voda može značajno smanjiti otjecanje do razine kakvo je postajalo na slivu prije početka izgradnje.
\end{abstract}

Ključne riječi: odvodnja oborinskih voda, zelena infrastruktura, projektni pljusak

\begin{abstract}
In this paper, an analysis of the stormwater drainage system at the University Campus in Rijeka is conducted. In addition to the classic stormwater drainage system, a sustainable stormwater drainage system has been proposed. The efficiency of this proposal was evaluated using a hydrological-hydraulic model. The results show that the implementation of a sustainable stormwater drainage system can significantly reduce runoff to pre-development levels.
\end{abstract}

Key words: stormwater drainage, green infrastructure, design storm

\footnotetext{
* GP KRK d.d., Stjepana Radića 31, 51500 Krk E-mail: andrea.maretic@gmail.com

** Sveučilište u Rijeci, Građevinski fakultet, Radmile Matejčić 3, 51000 Rijeka E-mail: nino.krvavica@gradri.uniri.hr
} 


\section{Uvod}

Odvodnja oborinskih voda novoizgrađenih gradskih naselja često predstavlja izazov zbog različitih prostornih ograničenja i mogućnosti priključenja na postojeći gradski sustav odvodnje otpadnih voda. Urbanizacijom i naglim razvojem gradova dolazi do povećanja nepropusnih površina, što smanjuje mogućnost infiltracije oborinskih voda u podlogu te povećava otjecanje površinskih voda. Negativni aspekti urbanizacije i tradicionalnog pristupa odvodnji oborinskih voda već su odavno poznati i detaljno dokumentirani u literaturi: povećava se volumen i brzina otjecanja oborina [1], skraćuje se vrijeme koncentracije [2] te se narušava kakvoća vode [3]. Urbanizirana su područja stoga izložena poplavama, s ponekad vrlo ozbiljnim posljedicama [4]. Kratkotrajne jake oborine su pritom jedan od glavnih uzroka poplava u urbanim sredinama [4]. Međutim, urbane poplave nastaju ne samo zbog izgradnje, koja značajno umanjuje infiltraciju vode, već i zbog neadekvatnog projektiranja sustava za odvodnju oborinskih voda. Nadalje, pluvijalne poplave rezultiraju prekomjernim površinskim tečenjem niz ulice, ceste, parkirališta i podzemnu infrastrukturu, a također mogu predstavljati i opasnost za ljudsko zdravlje zbog koncentracije onečišćujućih tvari i patogenih organizama [5].

Složeni problemi zahtijevaju inovativna rješenja i interdisciplinarne pristupe. Stoga, umjesto tradicionalnih rješenja u projektiranju sustava za odvodnju oborinskih voda i mjera ublažavanja pluvijalnih poplava koje se često temelje na izgradnji predimenzionirane podzemne infrastrukture, prilagodba na pluvijalne poplave nedavno je preusmjerena prema novim pristupima - tzv. održivim sustavima urbane odvodnje oborinskih voda (eng., Sustainable Urbane Drainage System, SUDS). U teoriji, SUDS pristup ima za cilj povratak urbaniziranog sliva hidrološkim uvjetima kakvi su postajali prije urbanizacije [6]. U praksi, to je integrirani pristup urbanom razvoju i tehnika upravljanja urbanim vodnim sustavima, koja predlaže nestrukturne i strukturne mjere za smanjenje rizika od poplava [6]. SUDS je izraz koji je prvi puta upotrijebljen u Velikoj Britaniji [7], ali slični pristupi upravljanju urbanim vodnim sustavima poznati su i kao Low Impact Development (LID) u SAD-u [8], Water Sensitive Urban Design (WSUD) u Australiji [6] ili Sponge City u Kini [9]. Filozofija SUDS pristupa temelji se na provedbi strukturnih mjera kao što su kišni vrtovi, bioretencije, lagune, infiltracijski jarci i bazeni, propusni kolnici i zeleni krovovi, poznatiji pod zajedničkim nazivom plavo-zelena infrastruktura $[6,10]$.

$\mathrm{U}$ ovome radu ukratko su prikazani rezultati opsežnih analiza provedenih u diplomskom radu [11] u kojem je originalno predložen koncept i provedena procjena učinkovitosti održivog sustava urbane odvodnje oborinskih voda na području Sveučilišnog kampusa na Trsatu u Rijeci. Pored procjene učinkovitosti SUDS pristupa, cilj ovoga rada je 
detaljnije prikazati metodologiju proračuna ovakvih sustava pomoću kombinacije računalnih alata za prostorne analize, numeričkih modela za hidrološko-hidrauličke proračune te modernih pristupa definiranju jakih oborina.

\section{Sveučilišni kampus na Trsatu}

Sveučilišni kampus smješten je u sjeveroistočnom dijelu grada Rijeke u naselju Trsat (Slika 1a,b). Položaj Sveučilišnog kampusa određen je Prostornim planom uređenja Grada Rijeke [12] unutar građevinskog područja GP-20 te obuhvaća veći dio površine bivše vojarne Trsat (Slika 1c). Pritom je manji dio vojarne Trsat namijenjen i razvoju Kliničkog bolničkog centra Sušak. Područje kampusa prostire se u smjeru sjeveroistokjugozapad.

Plan razvoja Sveučilišnog kampusa razrađen je Detaljnim planom uređenja područja Sveučilišnog kampusa i kliničkog bolničkog centra na Trsatu (DPU Kampus) [13]. Kako se radilo o velikom i složenom projektu, realizacija je planirana u nekoliko faza, pri čemu prva faza obuhvaća 9,4 ha, druga 16,4 ha, a treća konačna faza obuhvaća 29,4 ha površine [14]. Do ovoga trenutka, u potpunosti je izgrađena 1. faza i djelomično 2. faza, što uključuje sljedeće objekte: Akademija primijenjenih umjetnosti, Znanstveno-tehnologijski park, Filozofski fakultet, Učiteljski fakultet, Sveučilišni odjeli za matematiku, fiziku, informatiku i biotehnologiju, Građevinski fakultet, Studentska prehrana, Studentski servis i uprava Studenskog centra te paviljoni za studentski smještaj. Na kampusu je također izgrađena i pripadajuća komunalna infrastruktura, koja obuhvaća krajobrazno uređenje okoliša, prometne i parkirne površine, vodoopskrbni sustav, sustav odvodnje sanitarnih voda, sustav odvodnje oborinskih voda, javnu rasvjetu i ostalo (Slika 1d).

\section{Pregled predloženih rješenja sustava odvodnje oborinskih voda na Sveučilišnom kampusu}

Polazište za izgradnju sustava odvodnje oborinskih voda s područja Sveučilišnog kampusa na Trsatu je DPU Kampusa. Predloženim rješenjem oborinske vode prikupljaju se razdjelnim sustavom odvodnje koji se priključuje na postojeći mješoviti sustav odvodnje otpadnih voda grada Rijeke. Maksimalni očekivani protoci izračunati su pomoću racionalne metode za jednoliku oborinu jednogodišnjeg i dvogodišnjeg povratnog perioda, definiranu ITP krivuljom iz 1985. godine [15]. 


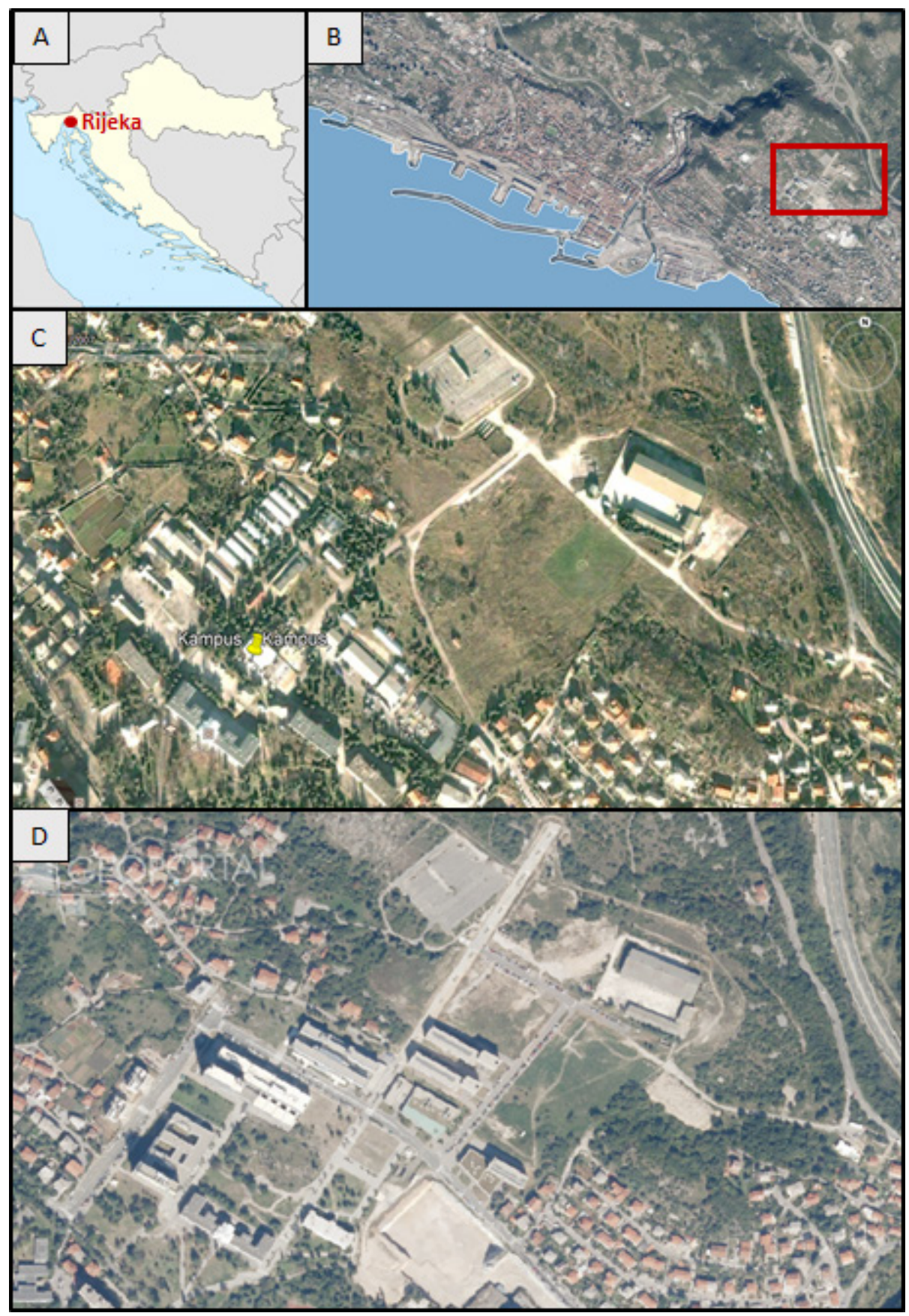

Slika 1. Položaj grada Rijeke (A), položaj Sveučilišnog kampusa na Trsatu (B), Satelitska snimka povijesnog stanja izgrađenosti (2007.) (C), Digitalna ortofoto snimka postojećeg stanja izgrađenosti (2018.) (D). 
Ovim proračunskim pristupom definirano je da će nakon završetka izgradnje Kampusa vršni protok oborinskih voda iznositi $4,04 \mathrm{~m}^{3} / \mathrm{s}$ za dvogodišnji povratni period. S obzirom da je kapacitet postojećih mješovitih kolektora iznosio $2040 \mathrm{l} / \mathrm{s}$, zaključeno je kako isti može primiti tek 50\% procijenjenih količina te da je potrebno pronaći optimalno rješenje koje se zasniva na retencioniranju i infiltriranju preostalih oborinskih voda na području Kampusa. Predloženo rješenje predlagalo je smanjenje vremena koncentracije sliva izgradnjom retencijskih bazena (uključujući i podzemne cijevne retencije velikog profila) te izgradnju infiltracijskih bunara za uvjetno čiste oborinske vode s krovova i pješačkih površina.

U međuvremenu su se uvjeti za priključak na postojeći mješoviti sustav odvodnje otpadnih voda promijenili, odnosno zaključeno je da se oborinske vode s područja Kampusa ne mogu priključiti na gradsku sustav odvodnje te je napisan novi projektni zadatak na temelju kojega je izrađeno i novo idejno rješenje [16]. Osnovna ideja novog rješenja je da se oborinske vode s područja Kampusa maksimalno zadrži u slivu, a da se višak oborinskih voda preusmjeri u potok Orehovica (sjeveroistočno od Kampusa). Pritom, kod dimenzioniranja hidrauličkih elemenata ovog sustava zanemarena je infiltracija oborinskih voda u podlogu zbog nepoznavanja točne upojnosti i smjera kretanja podzemnih voda. Predloženo rješenje dijeli sliv Kampusa na dva podsliva, gdje se oborinske vode sa nizvodnog podsliva prikupljaju $\mathrm{u}$ podzemnu retenciju te crpljenjem transportiraju u jezero-retenciju, smještenu na istočnom rubu sliva, dok se oborinske vode sa uzvodnog podsliva gravitacijski slijevaju u isto jezero-retenciju. Navedeno jezero je planirano kao višenamjensko (retencijsko-akumulacijsko-rekreativno), a preljevne vode se upuštaju u vodotok Orehovica. Niti ovo predloženo rješenje nije na kraju izvedeno. Stoga se u ovome radu daje alternativni prijedlog rješenja odvodnje oborinskih voda na području Kampusa, koji se temelji na održivom pristupu i zelenoj infrastrukturi.

\section{Metodologija}

Procjena učinkovitosti održivog sustava urbane odvodnje oborinskih voda provedena je u tri koraka, prema metodologiji predloženoj $\mathrm{u}$ radu Krvavice, Jaredića i Rubinića [21]. U navedenom radu razrađena je metodologija definiranja mjerodavne oborine za dimenzioniranje infiltracijsko-retencijskih sustava za odvodnju oborinskih voda prema integralnom pristupu. U prvom koraku provedena je prostorna analiza topografskih karakteristika sliva te pokrova zemljišta za povijesno stanje izgrađenosti (prije izgradnje Kampusa), postojeće stanje izgrađenosti (2018.) te planirano stanje izgrađenosti (nakon dovršetka Kampusa). U drugom koraku definirana je oborina, odnosno generiran je projektni pljusak za područje Rijeke, dok je u trećem koraku proveden niz 
hidrološko-hidrauličkih proračuna s ciljem procjene otjecanja sa sliva, usporedbe klasičnog i održivog sustava urbane odvodnje oborinskih voda te dimenzioniranja elemenata zelene infrastrukture.

\subsection{Prostorna analiza sliva}

Prostorna analiza sliva Sveučilišnog kampusa na Trsatu provedena je u QGIS računalnom programu [17]. Topografske karakteristike sliva određene su na osnovu kombinacije javno dostupnog digitalnog modela terena 25-m rezolucije (EU-DEM) [18] i digitaliziranih slojnica iz Hrvatske osnovne karte (HOK) u mjerilu 1:5000 [19], kako bi se odredili nagibi unutar sliva. Pokrov zemljišta određen je digitalizacijom Google satelitskih snimaka (za povijesno stanje), digitalnih ortofoto snimki (za postojeće stanje) [19] te DPU-a Kampus (za planirano stanje) [13]. Klase pokrova zemljišta određene su u skladu sa SCS metodom [20] za proračun otjecanja oborinskih voda, kako bi se jednoznačno dodijelio odgovarajući CN broj krivulje uz pretpostavku tla koje pripada hidrološkoj grupi B. Na Slici 2 prikazani su digitalizirani poligoni s pripadajućim CN brojevima krivulje za postojeće stanje izgrađenosti i skraćenim opisima pokrova zemljišta.

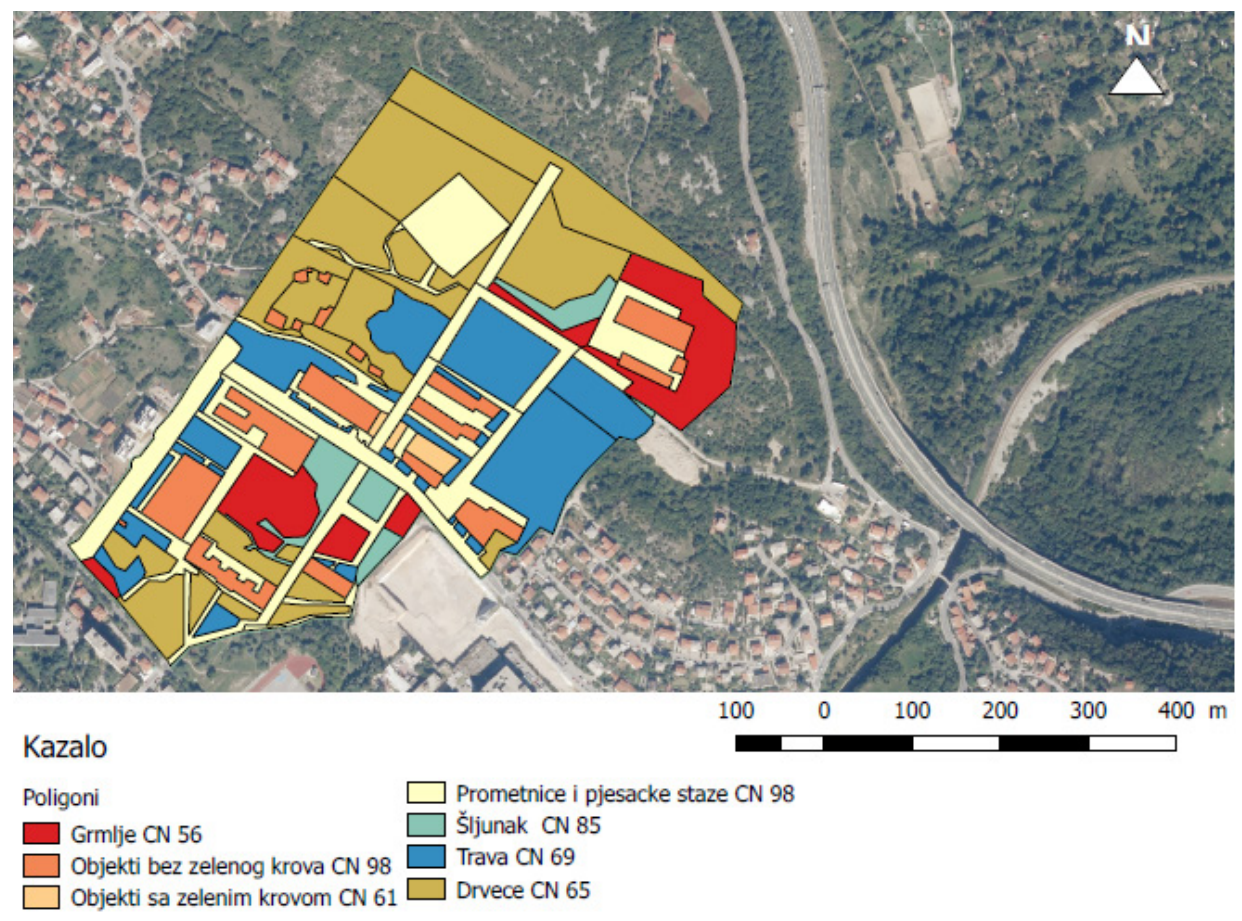

Slika 2. Digitalizirani poligoni s pripadajućim CN brojevima krivulje za postojeće stanje izgrađenosti Sveučilišnog kampusa na Trsatu [izradili autori] 
Ukupna površina analiziranog područja Sveučilišnog kampusa na Trsatu iznosi 26,3 ha. Za povijesno stanje izgrađenosti prosječni CN broj je 72,7, a udio nepropusnih površina (krovovi objekata bez zelenih krovova, prometnice i pješačke staze te ostale asfaltirane ili betonirane površine) iznosi 19,8\%. Prosječni CN broj za postojeće stanje izgrađenosti iznosi 77,3 , a udio nepropusnih površina iznosi $35,2 \%$. Iako se prosječni CN broj neznatno povećao, primjetno je povećanje udjela nepropusnih površina. Za planirano stanje izgrađenosti na području Kampusa napravljena je procjena udjela pojedinih klasa pokrova zemljišta na temelju podataka iz DPU-a [13]. Dodane su površine svih objekata i prometnica koje se planiraju izgraditi te je smanjen udio vegetacije. Procijenjeno je da će prosječni CN broj krivulje za planirano stanje izgrađenosti iznositi 84,4, a udio nepropusnih površina čak 58\%. Stoga je za očekivati da će se nakon dovršetka planirane izgradnje i volumen i protok oborinskih voda u budućnosti znatno povećati.

\subsection{Projektni pljusak}

Projektni pljusak (eng. design storm) definiran je vremenski varijabilnim intenzitetom oborine te stoga realnije opisuje jake oborine. Može se temeljiti na sintetičkim pljuskovima koji su izvedeni iz zabilježenih kišnih događaja ili, rjeđe, na pojedinim zabilježenim ekstremnim povijesnim oborinama. U prvom slučaju, vremenska raspodjela oborina računa se ili direktno iz HTP/ITP krivulja ili statističkom obradom niza zabilježenih oborina [10]. Proračuni projektnog pljuska za grad Rijeku već su provedeni u ranijem radu autora [21] prema metodi prosječne varijabilnosti oborinskog intenziteta. Proračun se temelji na ograničenom uzorku oborina i postojećim HTP krivuljama za grad Rijeku [22]. Na Slici 3 prikazan je hijetogram projektnog pljuska za trajanje $1 \mathrm{~h}$ i povratni period 5 godina (vjerojatnost godišnjeg premašenja 20\%) s vremenskim korakom od 2 min. Pritom, treba napomenuti da su hidrološko-hidrauličke analize provedene za niz različitih projektnih pljuskova za sva trajanja oborine od 1 do $24 \mathrm{~h}$.

\subsection{Hidrološko-hidraulički model}

Hidrološko-hidraulički model klasičnog i održivog sustava urbane odvodnje oborinskih voda izrađen je u računalnom programu EPA Storm Water Management Model 5.1 (SWMM) [23]. SWMM program se koristi za kontinuirane simulacije ili simulacije pojedinačnih događaja otjecanja oborinskih voda prvenstveno u urbanim područjima. Sastoji se od modula za hidrološke i hidrauličke procese te kakvoću vode. Osnovni model definiran je površinskim elementima (podslivovi, na kojima se generira otjecanje oborine), točkastim elementima (čvorovi, koji mogu predstavljati okna, ali i različite hidrauličke građevine, kao što su preljevi, retencije, pumpe, itd.) te linijskim elementima (kolektori, koji mogu predstavljati otvorene kanale i zatvorene cjevovode). 


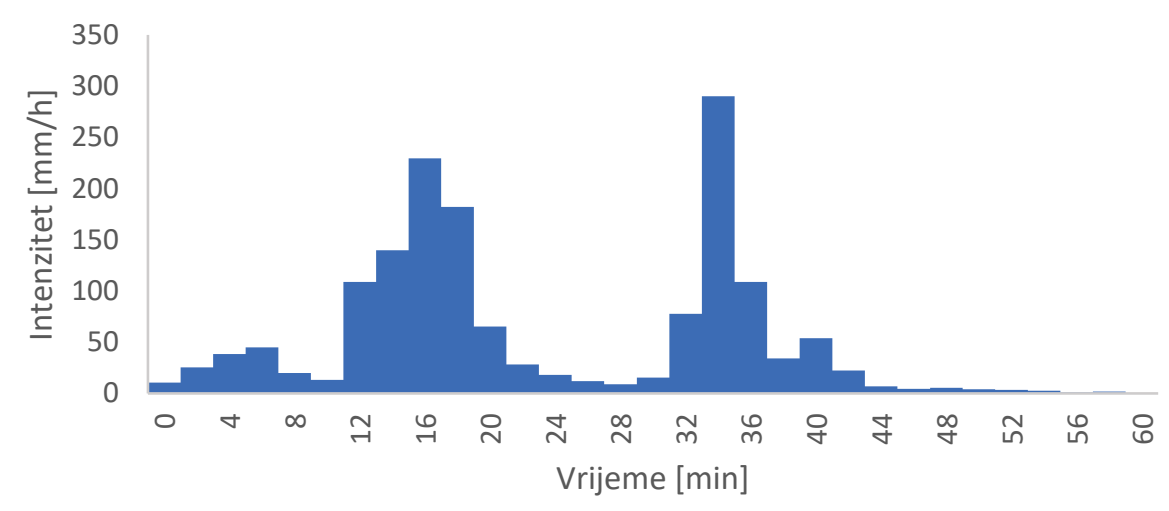

Slika 3. Projektni pljusak na području Rijeke za trajanje 1 h i povratni period 5 godina (vjerojatnost godišnjeg premašenja 20\%)

Konceptualni hidrološko-hidraulički model Sveučilišnog kampusa prikazan je na Slici 4. Pritom, podslivovi su definirani u skladu s budućim planiranim stanjem nakon što se završi izgradnja Kampusa. Tako isplanirani model budućeg stanja sastoji se od 63 podsliva. Svaki pojedini podsliv opisan je površinom, širinom, prosječnim nagibom te udjelom nepropusnih površina (koje su određene iz pokrova zemljišta). Infiltracija oborine u podlogu opisana je SCS metodom, odnosno CN brojem krivulje (također određenim iz pokrova zemljišta). Cjevovodi su postavljeni duž prometnica, a okna su postavljena samo na mjestima "priključka“ podsliva na sustav odvodnje ili na mjestima spoja dvaju ili više kolektora. Treba napomenuti da je ovo pojednostavljen model klasičnog sustava odvodnje u kojem je svaki podsliv spojen preko jedne točke na sustav odvodnje, dok je u stvarnosti broj priključaka i slivnika veći. Međutim, ovo pojednostavljenje u neznatnoj mjeri utječe na procjenu konačnih protoka sa cijelog slivnog područja. Uslijed nedostatka projektne dokumentacije ili projekta izvedenog stanja sustava odvodnje, nagibi cjevovoda su postavljeni paralelno s nagibom prometnice. Prosječna dubina nivelete cjevovoda u odnosu na kotu terena iznosi $2,0 \mathrm{~m}$. Pritom se vodilo računa o minimalnim i maksimalnim dozvoljenim padovima nivelete cjevovoda. U najnižoj točki sliva postavljen je izlazni čvor „Out1“ na kojem su promatrani izlazni protoci. Ova točka u stvarnosti predstavlja spoj na postojeći sustav odvodnje Grada Rijeke. 


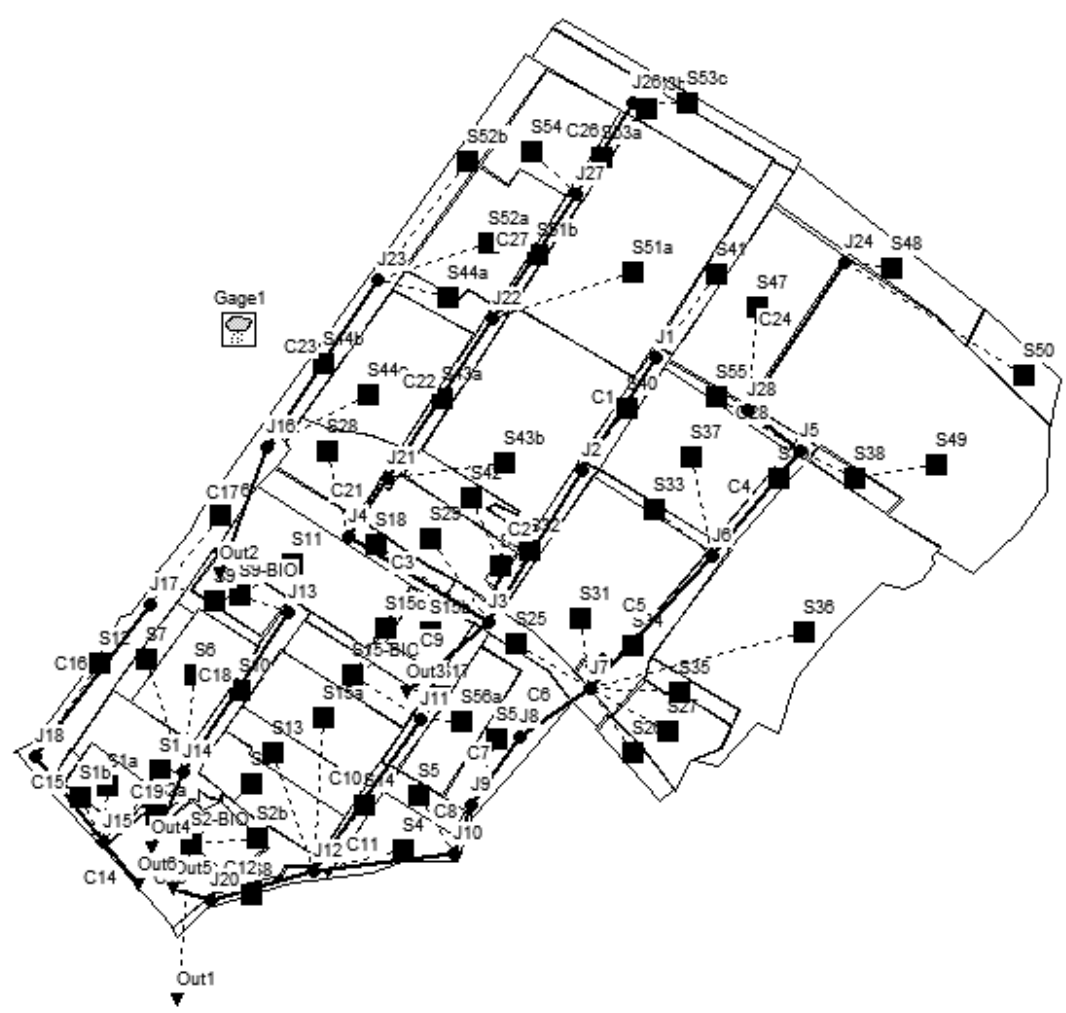

Slika 4. Shematski prikaz hidrološko-hidrauličkog modela Sveučilišnog kampusa za planirano stanje izgrađenosti u SWMM računalnom programu

Za planirano stanje izgrađenosti dan je prijedlog održivog sustava urbane odvodnje oborinskih voda, koji se zasniva na implementaciji zelene infrastrukture, odnosno izgradnji zelenih krovova (na većini novih objekata), propusnog betona na području šetnica i pješačkih površina te izgradnji tri podzemne infiltracijske retencije. Na Slici 5 prikazana je prostorna raspodjela navedene zelene infrastrukture. Pritom, zeleni krovovi i propusni betoni mogu samo smanjiti efektivnu oborinu s površine podsliva na koju oborina padne, dok infiltracijske retencije mogu prihvatiti i (vanjske) oborinske vode s uzvodnog dijela sliva. U infiltracijskim retencijama, oborinska voda se zadržava, procjeđuje, pročišćava, djelomično infiltrira u podzemlje, a jednim dijelom se putem drenažnih cijevi prelijeva u nizvodni dio sustava odvodnje oborinskih voda. Sva zelena infrastruktura definirana je kao karakteristika dijela podsliva u kojoj se nalazi ili kao zaseban podsliv odgovarajućih karakteristika. 


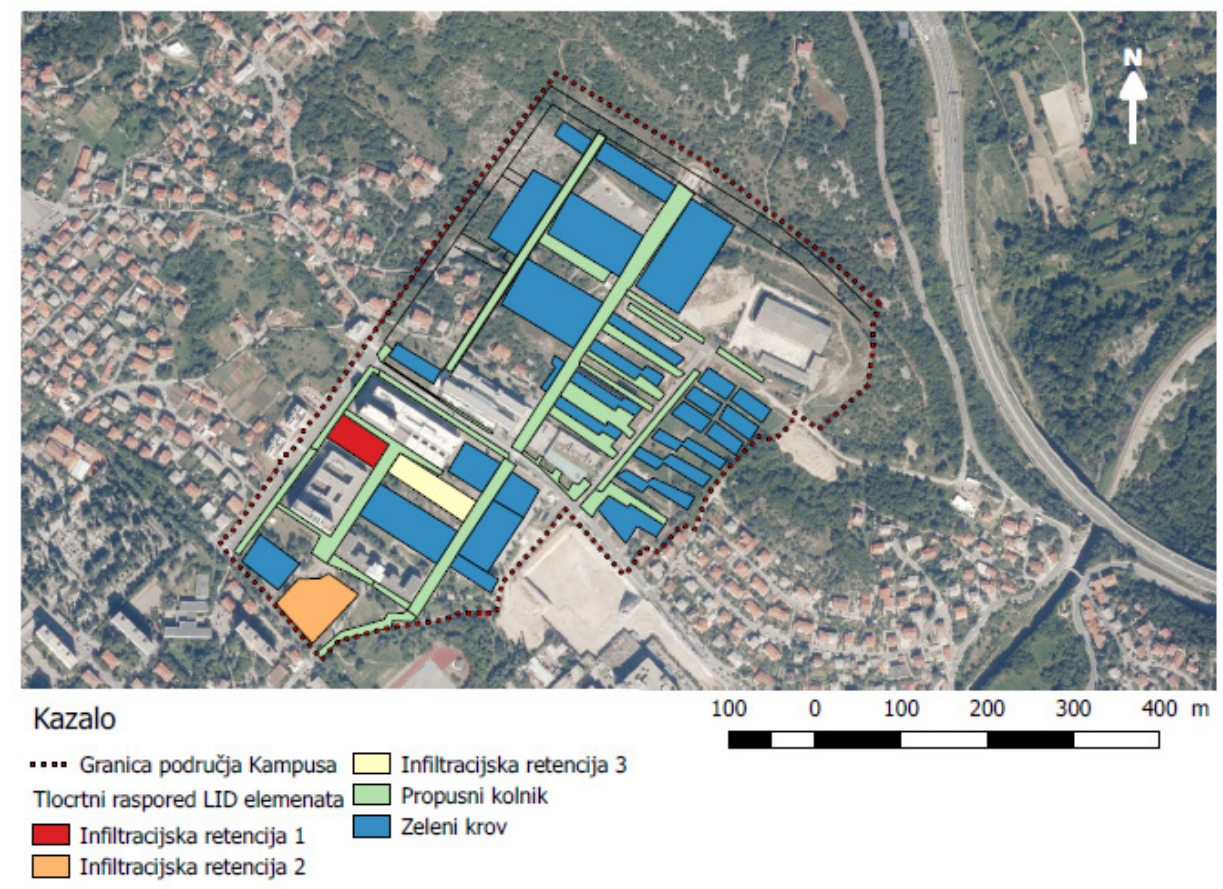

Slika 5. Prijedlog implementacije zelene infrastrukture na području Sveučilišnog kampusa na Trsatu za planirano stanje izgrađenosti [izradili autori]

Zeleni krovovi korišteni u SWMM modelu sastoje se od sloja vegetacije gdje visina berme iznosi $50 \mathrm{~mm}$, sloja tla debljine $120 \mathrm{~mm}$ te sloja drenažnog materijala debljine $250 \mathrm{~mm}$. Ukupna površina zelenih krovova iznosi $54.090 \mathrm{~m}^{2}$. Propusni kolnici sastoje se od sloja propusnog betona debljine $100 \mathrm{~mm}$, te drenažnog sloja od $200 \mathrm{~mm}$. Ukupna površina propusnih kolnika iznosi $15.080 \mathrm{~m}^{2}$. Ukupna površina svih infiltracijskih retencija iznosi $11.000 \mathrm{~m}^{2}$. Prva infiltracijska retencija ima površinu $2.100 \mathrm{~m}^{2}$, visinu berme od $50 \mathrm{~mm}$ te debljinu drenažno-infiltracijskog sloja od $2000 \mathrm{~mm}$. Druga infiltracijska retencija ima površinu $6.000 \mathrm{~m}^{2}$, visinu berme $50 \mathrm{~mm}$ te debljinu drenažno-infiltracijskog sloja od 3000 $\mathrm{mm}$. Treća infiltracijska retencija ima površinu $2.900 \mathrm{~m}^{2}$, visinu berme $50 \mathrm{~mm}$ te debljinu drenažno-infiltracijskog sloja od $2000 \mathrm{~mm}$. Ukupno je $30 \%$ površine sliva pokriveno zelenom infrastrukturom. Uslijed nedostatka pouzdanijih (izmjerenih) vrijednosti, brzina infiltracije podloge pretpostavljena je s niskom vrijednosti $0,5 \mathrm{~mm} / \mathrm{h}$. U infiltracijskom sloju postavljene su drenažne cijevi koje su spojene na sustav odvodnje kako bi postepeno ispuštale dio zadržanih i procijeđenih voda. Ugradnja drenažnih cijevi je u ovom slučaju potrebna zbog niskog infiltracijskog kapaciteta podloge. 


\section{Rezultati i diskusija hidrološko-hidrauličke analize}

Hidrološko-hidraulički proračuni otjecanja oborinskih voda provedeni su za povijesno, postojeće i planirano stanje izgrađenosti Sveučilišnog kampusa na Trsatu. Pritom, za planirano je stanje analiziran klasični sustav odvodnje oborinskih voda, koji se sastoji od sustava slivnika i cijevnih kolektora te održivi sustav urbane odvodnje oborinskih voda (SUDS), koji uključuje i zelenu infrastrukturu. Posebna pozornost je posvećena analizi učinkovitosti SUDS pristupa u smanjenju ukupnih protoka te dimenzioniranju elemenata zelene infrastrukture.

\subsection{Hidrološko-hidraulička analiza otjecanja sa sliva}

Na Slici 6 dan je prikaz hidrograma otjecanja oborinskih voda za povijesno, postojeće i planirano stanje otjecanja oborinskih voda na najnizvodnijoj točki sliva (Out1). Iako su analizirana sva trajanja oborine od 1 do $24 \mathrm{~h}$ za sva tri stupnja izgrađenosti, kritičnim trajanjem se pokazalo ono najkraće, od $1 \mathrm{~h}$, što je i očekivano s obzirom da je vrijeme koncentracije sliva kraće od $1 \mathrm{~h}$. Pritom, analizirane su oborine povratnog perioda 5 godina (vjerojatnost godišnjeg premašenja 20\%). Za povijesno stanje izgrađenosti dobivena je maksimalna vrijednost otjecanja u iznosu od 2,63 $\mathrm{m}^{3} / \mathrm{s}$, koja se javlja u približno 40 -minuti od početka oborine. Za postojeće stanje izgrađenosti dobivena je maksimalna vrijednost protoka u iznosu od $3,44 \mathrm{~m}^{3} / \mathrm{s}$, što je $31 \%$ veći protok u odnosu na povijesno stanje. Za planirano stanje izgrađenosti dobivena je maksimalna vrijednost protoka u iznosu od $5,85 \mathrm{~m}^{3} / \mathrm{s}$, što je više nego dvostruko veći protok (122\%) u odnosu na povijesno stanje. Ovi rezultati upućuju na činjenicu kako će se daljnjom urbanizacijom i izgradnjom na području Kampusa znatno povećati i količine površinskih tokova nastalih otjecanjem oborina.

Za planirano stanje izgrađenosti dodatno se analizirao i održivi sustav urbane odvodnje oborinskih voda uz implementaciju zelenih krovova, propusnih betona te tri infiltracijske retencije. SUDS pristupom postiglo se znatno smanjenje vršnih protoka s predmetnog sliva. Na Slici 7 prikazani su dijagrami otjecanja na najnizvodnijoj točki sliva za različita trajanja od 1 do $12 \mathrm{~h}$. Iz prikaza je vidljivo da je kritičan slučaj za oborinu trajanja $6 \mathrm{~h}$ te da se vršni protok povratnog perioda 5 godina smanjio sa $5,85 \mathrm{~m}^{3} / \mathrm{s}$ na $0,92 \mathrm{~m}^{3} / \mathrm{s}$, odnosno više od 6 puta. Usporedba vršnih protoka za povijesno, postojeće i planirano stanje (tradicionalni i održivi sustav) dana je na Slici 8. 


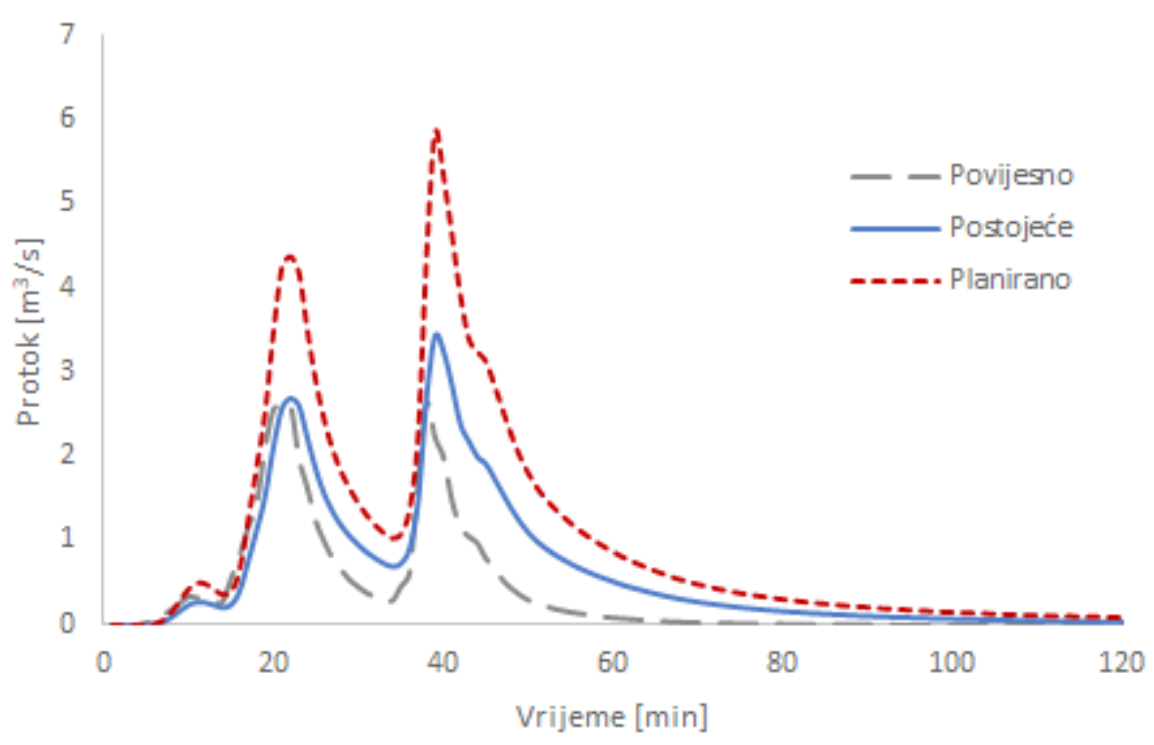

Slika 6. Hidrogrami otjecanja oborinskih voda na najnizvodnijoj točki sliva za povijesno, postojeće i planirano stanje izgrađenosti te oborinu trajanja $1 \mathrm{~h} \mathrm{i}$ povratnog perioda 5 godina (vjerojatnost godišnjeg premašenja 20\%).

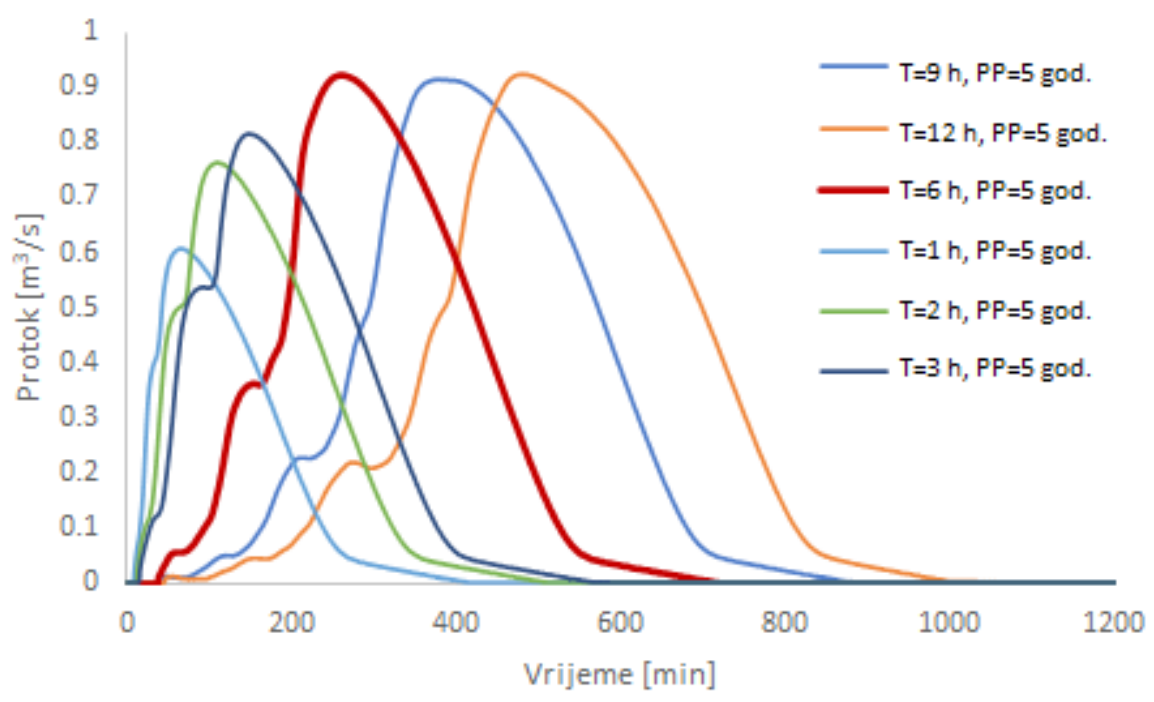

Slika 7. Hidrogrami otjecanja oborinskih voda na najnizvodnijoj točki sliva za planirano stanje izgrađenosti uz SUDS pristup za različita trajanja oborine i povratni period 5 godina (vjerojatnost godišnjeg premašenja 20\%). 


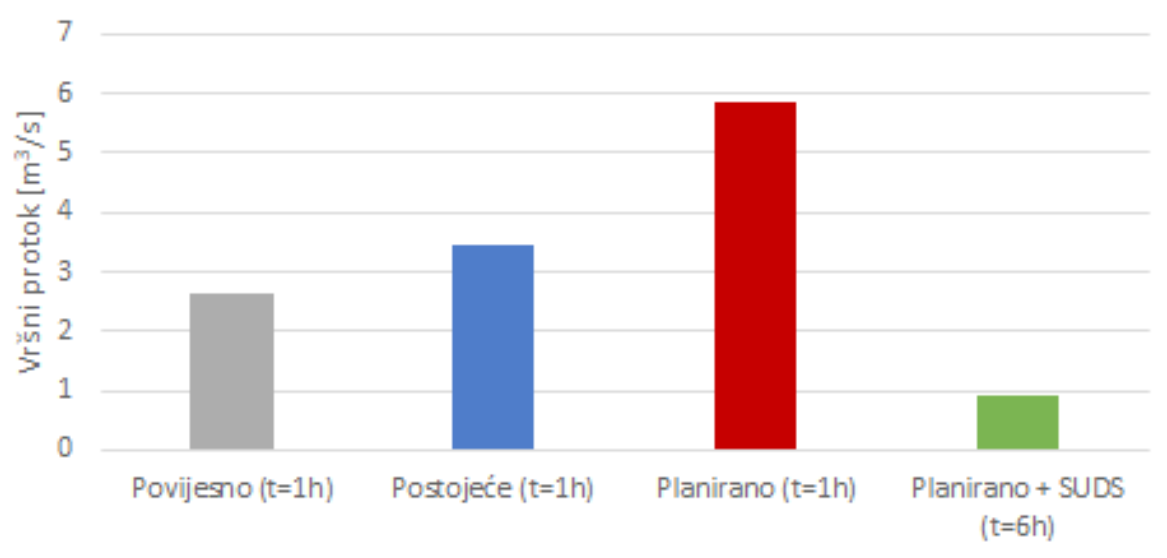

Slika 8. Vršni protoci otjecanja oborinskih voda za povijesno, postojeće i planirano stanje izgrađenosti (klasični i SUDS pristup) za oborinu povratnog perioda 5 godina (vjerojatnost godišnjeg premašenja 20\%).

\subsection{Dimenzioniranje infiltracijskih retencija}

U okviru hidrološko-hidrauličkih analiza sliva Sveučilišnog kampusa na Trsatu posebna pozornost posvećena je dimenzioniranju infiltracijskih retencija. Od tri analizirane retencije, u nastavku će se prikazati rezultati dimenzioniranja i funkcioniranja najveće retencije 2 .

Dimenzioniranje retencije provedeno je za oborinu povratnog perioda 10 godina (vjerojatnost godišnjeg premašenja 10\%), a pritom su analizirana sva trajanja od 1 do $24 \mathrm{~h}$ kako bi se odredilo kritično trajanje. Treba naglasiti kako, za razliku od dimenzioniranja profila cijevi gdje je kritično trajanje oborine jednako vremenu koncentracije sliva, kod ovakvih građevina nije moguće unaprijed znati kritično trajanje oborine zbog nelinearnog odnosa ulaznih protoka, infiltracije, promjene razine i izlaznih protoka kroz drenažne cijevi. U predmetnom slučaju, unaprijed je definiran maksimalni volumen retencije, odnosno tlocrtna površina i dubina retencije, a cilj dimenzioniranja je odabrati optimalnu drenažnu cijev koja će omogućiti minimalne izlazne protoke uz sprječavanje prelijevanja retencije. Iterativnim postupkom izračunato je da je potrebno postaviti dvije drenažne cijevi promjera $400 \mathrm{~mm}$ kako ne bi došlo do prelijevanja. Pritom, kritično trajanje oborine iznosi $12 \mathrm{~h}$. Na Slici 9 prikazan je ulazni i izlazni hidrogram iz retencije 2 , iz kojeg je primjetno da maksimalni ulazni protok iznosi $2,53 \mathrm{~m}^{3} / \mathrm{s}$, a izlazni protok $1,12 \mathrm{~m}^{3} / \mathrm{s}$. Na Slici 10 prikazana je promjena razine vode $\mathrm{u}$ istoj retenciji, koja $\mathrm{u}$ trenutku maksimalnog protoka doseže $296 \mathrm{~cm}$. 


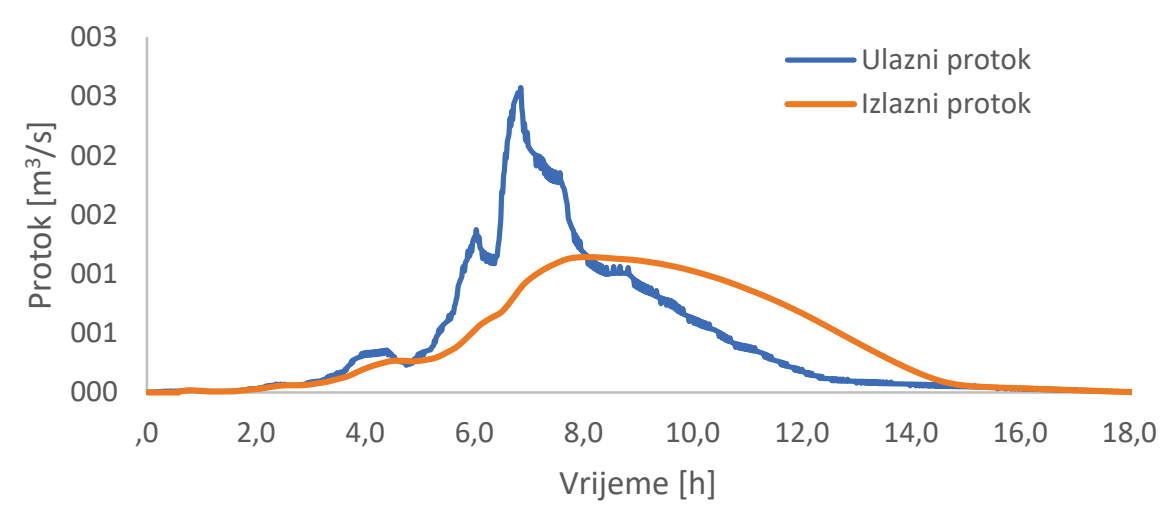

Slika 9. Ulazni i izlazni protok iz infiltracijske retencije 2 za oborinu trajanja 12 h $\mathrm{i}$ povratni period 10 god. (vjerojatnost godišnjeg premašenja 10\%)

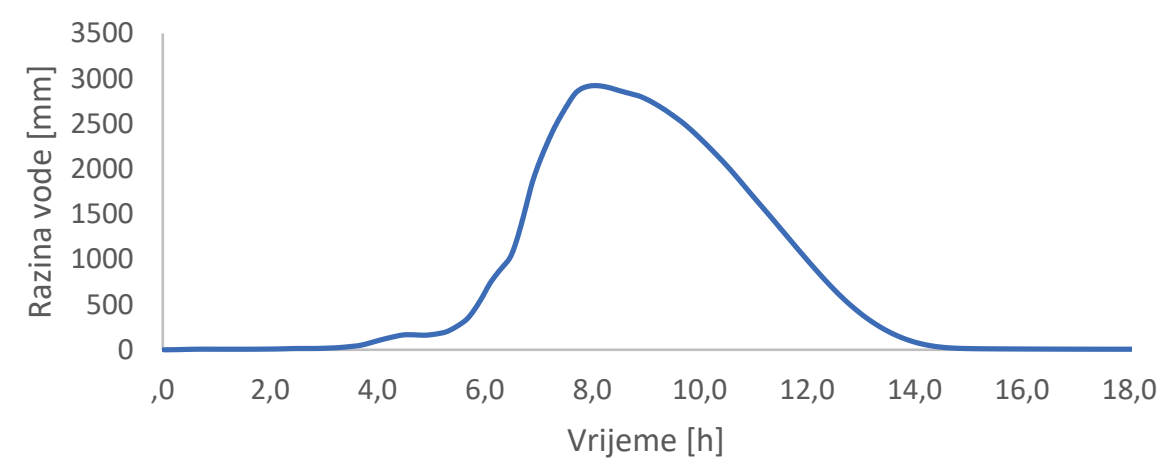

Slika 10. Promjena razine vode u infiltracijskoj retenciji 2 za oborinu trajanja 12 h $\mathrm{i}$ povratni period 10 god. (vjerojatnost godišnjeg premašenja 10\%)

\section{Zaključak}

Predmetni rad obradio je problematiku projektiranja održivih sustava urbane odvodnje oborinskih voda na primjeru Sveučilišnog kampusa na Trsatu u Rijeci. Rezultati su potvrdili otprije poznati negativan utjecaj urbanizacije na otjecanje oborinskih voda, prilikom čega se zbog povećanja nepropusnih površina značajno povećava volumen i protok oborinskih voda. Rezultati su također potvrdili visoku učinkovitost održivih sustava odvodnje u rješavanju problema količine oborinskih voda. Pored toga, rad je dodatno razradio predloženu metodologiju projektiranja održivih sustava s naglaskom na dimenzioniranje zelene infrastrukture, odnosno infiltracijskih retencija. Iz prikazanih rezultata mogu se dati sljedeće generalne smjernice: 
- provesti analizu otjecanja sa sliva u prirodnom stanju prije urbanizacije kako bi se odredila referentna vrijednost vršnih protoka koje treba nastojati zadržati i nakon izgradnje

- provesti hidrološko-hidrauličke proračune pomoću numeričkih modela i nestacionarnih simulacija

- koristiti projektni pljusak koji daje realnije rezultate otjecanja u odnosu na jednoličnu oborinu

- provesti niz proračuna za različita trajanja oborine kako bi se odredilo kritično trajanje koje odgovara maksimalnom retencijskom volumenu.

Pored analize učinkovitosti održivih sustava u upravljanju količinama oborinskih voda, poznat je njihov povoljan utjecaj i na kakvoću vode, što nije razmatrano u ovome radu, ali je svakako potrebno uključiti u proces planiranja i projektiranja sustava oborinske odvodnje. Također, zbog nedovoljnog poznavanja biološko-kemijskih procesa, potrebno je i unaprijediti razumijevanje učinkovitosti zelene infrastrukture u pročišćavanju onečišćenih oborinskih voda te zaštite vodnih resursa.

\section{Literatura}

[1] Jennings, D.B., i Jarnagin, S.T. (2002) Changes in Anthropogenic Impervious Surfaces, Precipitation and Daily Streamflow Discharge: a Historical Perspective in a Mid-Atlantic Subwatershed. Landscape Ecology, 17 (5), str. 471-489.

[2] Braud, I., Breil, P., Thollet, F., Lagouy, M., Branger, F., Jacqueminet, C., Kermadi, S., i Michel, K. (2013) Evidence of the Impact of Urbanization on the Hydrological Regime of a Medium-Sized Periurban Catchment in France. Journal of Hydrology, 485, str. 5-23.

[3] Makepeace, D.K., Smith, D.W. i Stanley, S.J. (1995) Urban Stormwater Quality: Summary of Contaminant Data. Critical Reviews in Environmental Science and Technology, 25 (2), str. 93-139

[4] Chen, Y., Zhou, H., Zhang, H., Du, G. i Zhou, J., (2015) Urban Flood Risk Warning Under Rapid Urbanization. Environmental Research, 139, str. 3-10.

[5] Fraga, I., Charters, F.J., O'Sullivan, A.D. i Cochrane, T.A., (2016) A Novel Modelling Framework to Prioritize Estimation of Non-Point Source Pollution Parameters for Quantifying Pollutant Origin and Discharge in Urban Catchments. Journal of Environmental Management, 167, str. 75-84.

[6] Fletcher, T.D., Shuster, W., Hunt, W.F., Ashley, R., Butler, D., Arthur, S., Trowsdale, S., Barraud, S., Semadeni-Davies, A., Bertrand-Krajewski, J.L. i Mikkelsen, P.S., (2015) SUDS, LID, BMPs, WSUD and More - The Evolution and Application of Terminology Surrounding Urban Drainage. Urban Water Journal, 12 (7), str. 525-542. 
[7] Woods-Ballard, B., Kellagher, R., Martin, P., Jefferies, C., Bray, R., i Shaffer, P. (2007). The SUDS Manual (Vol. 697). London: Ciria.

[8] Coffman, L.S. i France, R.L., (2002) Low-Impact Development: An Alternative Stormwater Management Technology. Handbook of Water Sensitive Planning and Design, 2002, str. 97-123.

[9] Li, Z., Xu, S. i Yao, L., (2018) A Systematic Literature Mining of Sponge City: Trends, Foci and Challenges Standing Ahead. Sustainability, 10(4), str. 1182.

[10] Dietz, M.E., (2007) Low Impact Development Practices: A Review of Current Research and Recommendations for Future Directions. Water, Air, and Soil Pollution, 186(1-4), str. 351-363.

[11] Maretić, A. (2020.) Idejni koncept održivog sustava odvodnje oborinskih voda Sveučilišnog kampusa u Rijeci. Diplomski rad. Rijeka: Građevinski fakultet.

[12] Prostorni plan uređenja grada Rijeke (SN PGŽ, 31/03)

[13] Detaljni plan uređenja područja Sveučilišnog kampusa i kliničkog bolničkog centra na Trsatu (SN PGŽ, 29/05)

[14] Ožanić, N., i Hero, M. (2010.) Sveučilišni kampus u Rijeci na Trsatu. Građevinar, 62(5), str. 377-388.

[15] Hidrološko-hidrotehnička istraživanja oborinskih voda područja GUP-a Rijeka (1985.) Građevinski institut Zagreb.

[16] Santin, G., Uzelac, B., Sokol, M. i Sušanj, I. (2007) Kanalizacijski sustav oborinskih voda s područja Sveučilišnog kampusa Trsat u Rijeci - idejno rješenje. Hrvatske vode.

[17] QGIS Geographic Information System. https://www.qgis.org/ (1. srpnja 2021.)

[18] EUDEM. https://land.copernicus.eu/imagery-in-situ/eu-dem/eu-dem-v1.1 (1. srpnja 2021.)

[19] DGU Geoportal. https://geoportal.dgu.hr/ (1. srpnja 2021.)

[20] NRCS (2004) National engineering handbook: Part 630-Hydrology. USDA Soil Conservation Service: Washington, DC, USA.

[21] Krvavica, N., Jaredić, K., i Rubinić, J. (2018.) Metodologija definiranja mjerodavne oborine za dimenzioniranje infiltracijskih sustava. Građevinar, 70(8), str. 657-669.

[22] Rubinić, J., Lukarić, S., i Rukavina, J. (2009.) Engineering Analysis of ShortTerm Heavy Rainfalls-Rijeka Area Case Study. U: Zborniku radova Suvremene metode odvodnje oborinskih voda urbanih sredina na obalnim područjima. Građevinski fakultet Sveučilišta u Rijeci, Rijeka, Hrvatska.

[23] EPA Storm Water Management Model (SWMM). https://www.epa.gov/ water-research/storm-water-management-model-swmm (1. srpnja 2021.) 